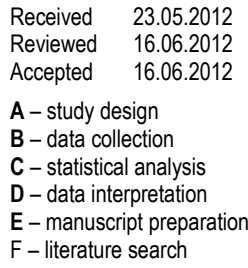

\title{
Protection of natural wetlands - the examples of conflicts
}

\section{Waldemar MIODUSZEWSKI ${ }^{1)}$ ABCDEF, Tomasz OKRUSZKO ${ }^{2)}$ ABCDEF}

\footnotetext{
${ }^{1)}$ Institute of Technology and Life Sciences, Department of Water Resources, ul. Hrabska 3, Falenty, 05-090 Raszyn, e-mail: w.mioduszewski@itep.edu.pl

2) The University of Life Sciences in Warsaw, Faculty of Engineering and Environmental Science, ul. Nowoursynowska 159, 02-776 Warszawa, e-mail: t.okruszko@levis.sggw.pl
}

\begin{abstract}
Wetlands as one of the most valuable ecosystems are subjects of legal protection. Except ecological value they play important role in water management. Wetlands slow down the outflow of water from river basins and protect the water quality in the agricultural area. Therefore many artificial wetlands are constructed in some countries. The most valuable natural wetlands are protected as National Parks - the highest form of protection. Maintaining high degree of moisture of soil that is a condition that must be fulfilled to preserve the value of these areas can cause conflicts in using the adjacent areas. The paper presents an analysis of conflict situations that occurred in the Biebrza, Narew and Kampinos National Parks. Drainage of the excess water from the built-up area or from the areas used for agricultural purposes interferes with the natural flow regime in the protected areas. The analysis allowed identifying the possible compromise solutions.
\end{abstract}

Key words: environmental protection, national parks, water management, wetlands

\section{INTRODUCTION}

For many years wetlands have been submitted to special attention of the international community. This situation results from the fact that human economic activity, including agriculture, led to drying and elimination of many wetlands in the world, especially in Europe. Nowadays, there is no doubt about need of wetlands preservation in their natural state. Wetlands protection is necessary not only because of the biological diversity of these areas and the occurrence of many rare species of flora and fauna but also because their function in water management. The natural wetland slow down the outflow of water from river basins. They protect the surface water from the diffuse agricultural contamination. Protection of wetlands is a target of many national and international documents starting from the Ramsar Convention (RC) and ending with the Water Framework Directive (WFD). WFD and its implementation in the Polish Water Law clearly oblige Poland to protection of aquatic and water - related ecosystems. In Poland, most of the areas protected by law are forests and bogs due to their high natural value. Areas with high humidity are present in most of Polish National Parks. Some National Parks have been established primarily for the conservation of wetlands. Parks where large areas of wetlands are located are: Biebrza, Narew, Warta Estuary and Polesie (Fig. 1). Also in the Kampinos National Park nearly $40 \%$ of the protected area is wetlands.

Protection of wetlands often collides with plans of the local society. This situation concerns mainly farmers operating within and in the vicinity of the protected areas. Also conflicts arising from the society desire to build households in the areas of increased humidity that are considered to be attractive locations occur. Protection of wetlands means preservation of high ground water level as well as the long term occurrence of water at the ground surface and high water level in streams. Implementation of these measures can be difficult due to frequent lack of water after dry periods and high moisture level of the soil 
that cause difficulties in agriculture use of the protected area and its vicinity. Conflicts arise in such situations and they can set a lot of people hostile to the idea of wetlands protection. Moreover, part of the society considers wetlands as areas hostile to humans as it was common many years ago. Many experiments that had been performed show that the nature conservation process is more effective when the local community is involved. It is difficult to protect large areas from devastation even with help of a group of well trained and dedicated to the nature young people.

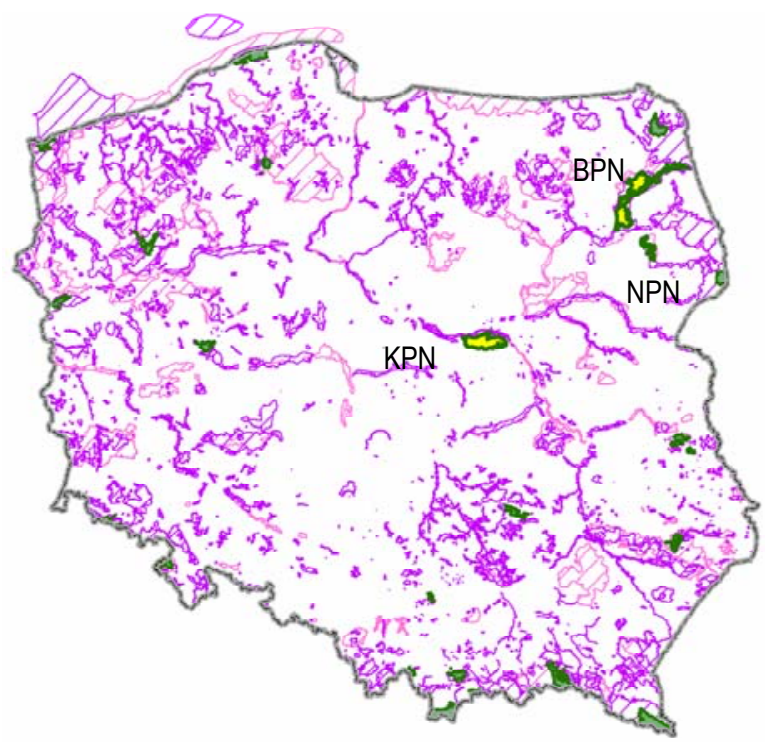

Fig. 1. Areas protected in Poland due to their high natural value, KPN - Kampinos National Park, NPN - Narew National Park, BPN - Biebrza National Park

The aim of this paper is not a comprehensive presentation of the problems and conflicts in Poland arising between present owners of wetlands and the need to protect nature as there are a lot of conflict sites and they have never been registered or studied in depth. The aim of this study is to describe the three selected examples of wetlands located in the national parks for which protection is necessary to maintain a high level of surface and ground water while public use of the terrain demands decrease of water level.

\section{MATERIALS AND METHODS}

In summer 2010 high precipitation causing increase of surface and ground water level occurred. Meadows used for agricultural purposes situated in the vicinity of the borders of the Biebrza and Narew National Parks as well as urban areas in the vicinity of the Kampinos National Park were flooded. Observations and research were conducted to define reasons of flooding as well as to find solutions to prevent flooding of agricultural lands without causing any threats to protected areas within national parks. The research included measurements and analysis of the surface and ground water table, evaluation of hydrau- lic conductivity, evaluation of state of the existing hydrographic network, description of actual scope of flooding and assessment of water management in the area. Results of measurements and observations allowed generalization of the observed phenomena. Summary of the research has been presented for each Park separately while synthetic conclusions include all the case studies. Obtained results are of general nature and may be applied to other cases.

\section{RESULTS AND ANALYSIS}

Conflicts in three national parks have been analysed. Due to elevated level of surface and ground waters citizens operating in these areas have suffered. Elevated water level is a desirable feature in all discussed areas. In all three parks organic soil degradation and adverse vegetation transformation resulting from small water resources and influence of the drainage system that had been constructed decades ago can be observed. Therefore various measures for limiting water outflow from the area have been proposed. The aim can be obtained by construction of thresholds on water courses. Maintenance of water courses has been abandoned what causes growth of sediments in the bottom and vegetation development. These measures increase hydraulic resistance of water courses what cause elevation of water level in the course and increase of ground water level in the vicinity of the course. Flooding of the area as well as increased level of surface and ground water are beneficial to the protection of natural values of wetlands but they are rarely accepted by the owners of adjacent areas.

Biebrza National Park. Biebrza National Park is the largest swamp park in Poland. It is located in the valley of the river where attempts of drainage had been made several times in the past. The aim of drainage was to ease intensification of meadows and pastures agricultural use. The part of the valley that is under law protection has kept its valuable features and is still extensively used for agricultural purposes. Also, the river has never been regulated. By contrast, most of Biebrza tributary rivers have been straighten and its valleys have been drained by open ditches. These areas are still used for agricultural purposes mainly cattle and milk production. Therefore, drained areas are significant to the local economy. Their value is even higher as mineral soils are rare in this region and their quality is poor.

Brzozówka (Fig. 2) is an example of the river valley where water conditions are regulated. The river itself has been regulated and the drained valley and existing devices allow irrigation. Cattle production basing on use of valley meadows has developed. In years when precipitation is high and in times with ex cess of water due to crops demands water is drained to Brzozówka that is a tributary river of Biebrza. Hydrographic network of the area has been shown in Fig. 2. 


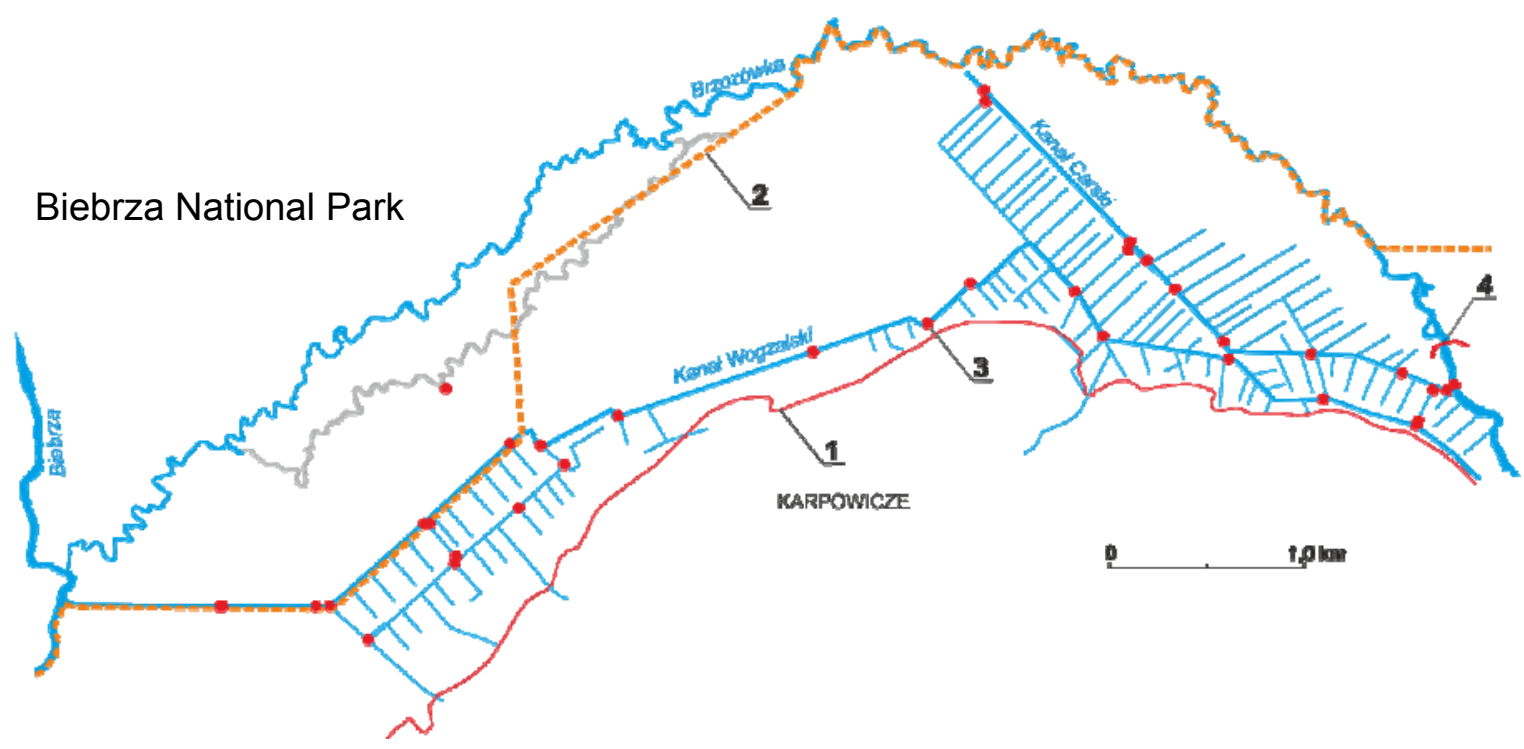

Fig. 2. Hydrographic network in the valley of Brzozówka:

1 - border of the valley, 2 - border of the Biebrza National Park, 3 - weirs, 4 - weir on Brzozówka River

Maintenance of the Brzozówka and Biebrza Rivers has been abandoned since establishing of the National Park. No removing of sediments excess or plant cover in the river bed occurred. These measures led to significant decrease of the cross-section, reduction of the hydraulic capacity and increase of water level. Present state of the river prevents water drainage with use of drainage ditches. Research carried out in 2010 defined sites located in the river valley which are particularly responsible for difficulties in water drainage. In periods when significant amounts of precipitation occur meadows are flooded for the most part of the time and farmers lose their yields. Partial removing of the silt excess in the Brzozówka bed has been allowed in the area of the mouth of the river due to the state of the environment and agricultural demands. Procedure of removing of the part of plants and silt in the river bed and one of the slopes of the valley performed in 2011. This action improved moisture level on meadows used for agricultural purposes but it was also criticized by some ecologists as an unnecessary concession to the farmers. Until now no negative impact on flora and fauna of the Park was observed. On the other hand, it is a fact that earthworks were not performed in compliance with engineering rules and recommendations presented in the survey. It has been recommended that work should concentrate on the selected sections to remove local bottlenecks instead of widening river bed along its entire length. Moreover, leaving of the additional sediments on the river banks is not in compliance of the principles of earthworks. The prism is a contrast to the surrounding plants and it makes it difficult to the nature to return to its natural state.

The decision that was taken in the Biebrza National Park was a courageous one. Despite positive opinion given in the survey negative impact might have occurred. Neighbourhood relations in this part of the Park improved considerably. Similar, but not so obvious, situations occur in other estuaries of the Biebrza tributary rivers in the park. In these sites removing of the sediments is not allowed due to the fact that flooding of the valley is not that harmful to the grasslands production while conservation works are threat to the natural environment. The existing conflict was a reason why farmers decided to illegally remove an excess of sediments in one of the tributaries. The action was performed in the night to avoid legal responsibility. It seems that it is necessary to undertake remedial measures to avoid such activities in the future and it does not mean punishing the people responsible. It should be made clear that farmers are the only ones who shouldn't be charged with costs of conservation as it is a responsibility of the whole society.

Narew National Park. For many years Narew valley has been a granary of poor quality grass for farms in the area. Drainage work has started in the mouth of the Biebrza River and gradually went up the river. The work has started with construction of the new river bed of the large scale cross section that was supposed to accommodate the high water without flooding the valley. At the end of 1970s' due to the promotion of the Ramsar Convention society became more aware that these areas are environmentally valuable and should be protected. In 1982 drainage works have been ceased. The river has been regulated on the section from Żółtki to ca. $900 \mathrm{~m}$ above Rzędziany. A new, wide river bed has been constructed as well as two weirs (Babino and Rzędziany). However, a drainage system that had been planned (drainage and supplying ditches) has not been constructed. A dike Rzędziany - Pańki that had been constructed for technological purposes has been considered a boundary above which natural water relations should be pre- 
served. The same dike has been defined as the limit of the National Park while it's establishing (Fig. 3). A section of the river where only the regulatory works have been performed is a buffer zone. The buffer zone separates the natural part of the valley (above the dike) from the one that is intensively used for agricultural purposes (below Żółtki).

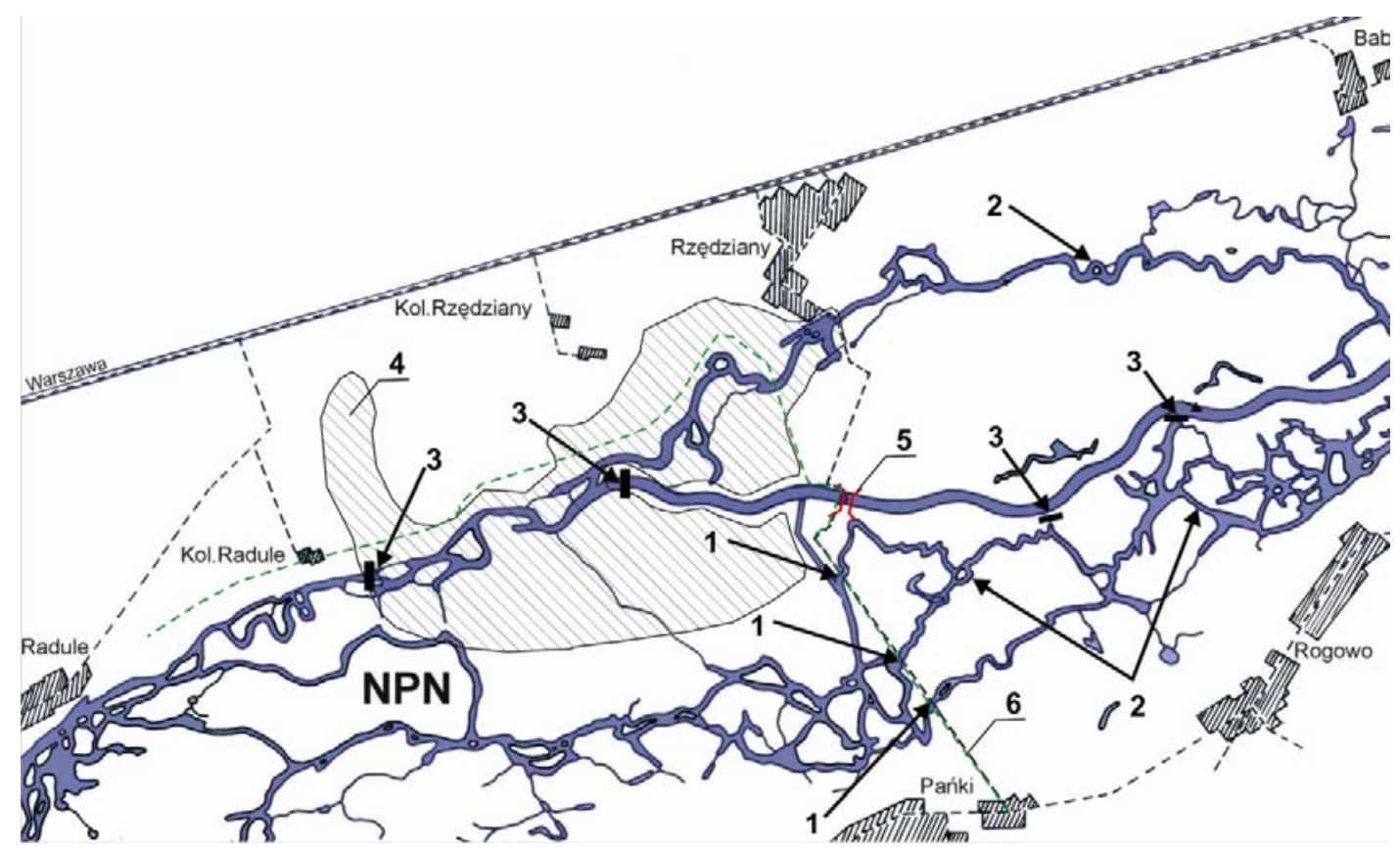

Fig. 3. Hydrographic network of the Narew National Park and its buffer zone: 1 - wooden bridges, 2 - desilted meanders, 3 -thresholds, 4 - flooded areas, 5 - weir Rzędziany, 6 - border of the Narew National Park

It was assumed that the weir Rzędziany will dam the river up to the level ensuring sustaining high humidity of the protected wetlands. According to these assumptions level of $110.70 \mathrm{~m}$ a. s. 1. has been defined in the legal water permit. Also, in haymaking period it has been allowed to lower the damming level. Despite high water damming at the weir unfavourable changes of the vegetation in the park in the zone up to $900 \mathrm{~m}$ from the dike have been observed. Therefore, in the Park Protection Plan from 1992 it has been suggested to elevate the damming level on the weir and its accommodation to a year-round damming. These suggestions have not been fulfilled.

Polish Society for Birds Protection (PTOP) undertook a very difficult and responsible task of restoration of the water conditions in the buffer zone. A series of tasks, as presented in figure 3, has been performed. At the dike Rzędziany - Pańki steel culverts have been replaced by wooden bridges to allow the more significant water inflow to the buffer zone. Technical works have been also performed in the Park. Two thresholds aiming at directing the flow towards old meanders have been constructed. A threshold situated close to the weir is damming water of the Narew River up to the height of $70 \mathrm{~cm}$ and directs most of the flow into the left, old river bed. This action caused elevation of the groundwater level at the meadows situated on the left side of the valley at the height of the Rzędziany village (Fig. 3).
A significant part of the Narew valley situated within the limits of the Park as well as in the buffer zone belongs to the private investors and it is used as intensive meadows and pastures. Farmers are making various efforts to intensify the agricultural use of these areas. Most of the land owners have been opposed to the action aiming at increasing the soil humidity of the area since the establishment of the Park. It is a reason of the number of conflicts that occur at the border of nature conservation and agriculture. On the right side of the regulated river bed, within limits of the buffer zone where intensive restoration works take place no conflicts occur due to the fact that the land belongs to the PTOP.

Farmers are demanding liquidation of the damming threshold (mainly the one situated closer to the weir) and lowering of the damming level at the weir. The second named demand has been already reached and a new legal water permit defines damming level at $110.20 \mathrm{~m}$ a. $\mathrm{s}$. 1 . which is $50 \mathrm{~cm}$ lower compared to the previous permit. This decision has been challenged by the Regional Water Management Board in Warsaw at the request of the Director of the Park. At present lover level of damming is sustained but it has not significantly improved farmers situation. Decrease of water level at the weir causes mainly changes of humidity of vast areas situated on the right side of the river that are not useful for agriculture (Fig. 3). The additional negative phenomenon is the excessive out- 
flow of water from the protected area situated within borders of the Park to the buffer zone under the wooden bridges that have been constructed. At high water levels a concentration of the flow causing erosion occurs. Deepening of the river bed of the meanders under the wooden bridges and their vicinity occur. The negative influence increases during periods when water damming level at the weir is low. Symptoms of peat bogs drying are already visible above the dikes.

The present situation is unsatisfactory due to the agricultural use of the meadows and yet environmental values of the wetlands in the Park are still not protected. Due to the need of meadows and pastures use intensification areas of excessive humidity occur within limits of the Park and its buffer zone along the old riverbed as a result of redirecting of the large flow. Liquidation of the thresholds with sustaining the low damming level at the weir would be a disaster for the Park. Accelerated degradation of meanders network being the basic element of the multi through river and the most valuable element that should be protected in the Park would occur in the first place. The adverse impact would reach up to several kilometres up the river.

The situation described above is an example of a moment when finding a compromise is very difficult if not impossible. The only reasonable solution is to buy out the area adjacent to the buffer zone as it had been suggested in the Park Protection Plan from 1992. This solution would allow using the weir Rzędziny for environmental protection purposes. Due to the conservation of the wetlands water damming at the weir Rzędziny is to important factor stabilizing soil humidity within the Park to use it for other purposes at the same time. It results mainly from the location of the weir at the border of to significantly different areas (the Park and its buffer zone). Performing water management in the area in the way fulfilling demands of agriculture and environment at the same time is difficult due to the fact that groundwater table below the dike is located lower than in the Park.

Ensuring the proper water conditions resulting from the need to protect the natural values of the Narew valley does not raise any major technical difficulties. Water damming level at the weir should be elevated while the constructed thresholds should be saved as elements that can limit the negative impact on the environment in case of the wire failure. These decisions are not easy to make due to the agricultural use of the area within the Park and its buffer zone. The lower threshold might require a difficult reconstruction to limit the recharge of the old, left sided river bed. Such need arises from the need to allow agricultural use of the areas located along the river as well as to drain the road leading from Warsaw to Białystok.

The situation presented above leads to one more conclusion, namely that, even while making decisions that might be very beneficial for the environment one should always keep in mind the interest of his neighbours - farmers and the Park at the same time. Improvement of the conditions in one area (e.g. the buffer zone) can cause a hazard in another one that might be of even greater natural value (e.g. the National Park).

The Kampinos National Park. The Park undergoes a significant of anthropogenic pressure arising from its location in the vicinity of Warsaw. This problem concerns mostly to the outer limits that are a perfect place to locate a house, especially for people valuing peace and nature.

The Kampinos National Park has been established to protect two different ecosystems. These are forests growing on sand dunes and wetlands occurring between dunes (Fig. 4). Wetland areas are the particularly vulnerable ones. In its natural state within the present limits of the Park these were the areas without any visible watercourses. A dense network of shallow depressions draining the excess water to the Bzura River was present. To allow agricultural use of wetlands Łasica Channel was constructed at first and next many other, smaller channels and ditches to drain the area (Fig. 4). Observations and research that had been performed show the progressive degradation of the organic matter caused mainly by drying as an effect of drainage ditches construction.

The state of aquatic and water - dependent ecosystems within the Park is well recognized. Various scientific research and expertise had been performed. The area of the Park has been equipped with an extensive system of water monitoring. Among the other, over 50 piezometers have been drilled to measure groundwater level. In the wetlands area groundwater table remains close to the surface of the ground and do not falls below $1.5 \mathrm{~m}$ below the ground surface (Fig. 4). In its natural conditions, before the drainage ditches had been constructed, the groundwater table maintained near the surface throughout the year. Over 10 years of observations of the groundwater table show that in the significant part of the Park a gradual lowering of the groundwater table occur. There are only few areas where elevation of the groundwater table is observed (Fig. 4). The process of lowering of the groundwater table must be stopped if we want to preserve valuable natural wetlands of the Kampinos National Park for future generations. All the analysis and scientific research indicate the need to minimize the outflow of spring water and the precipitation from the Park as soon as possible. It might allow terminating the process of drying and will limit the process of degradation of organic soils as well as stop the adverse changes in flora and fauna. Also, in a critical situation, one can consider recharge with use of water from the Vistula River.

The easiest way to improve the water conditions within the Park would be liquidation of the most of 


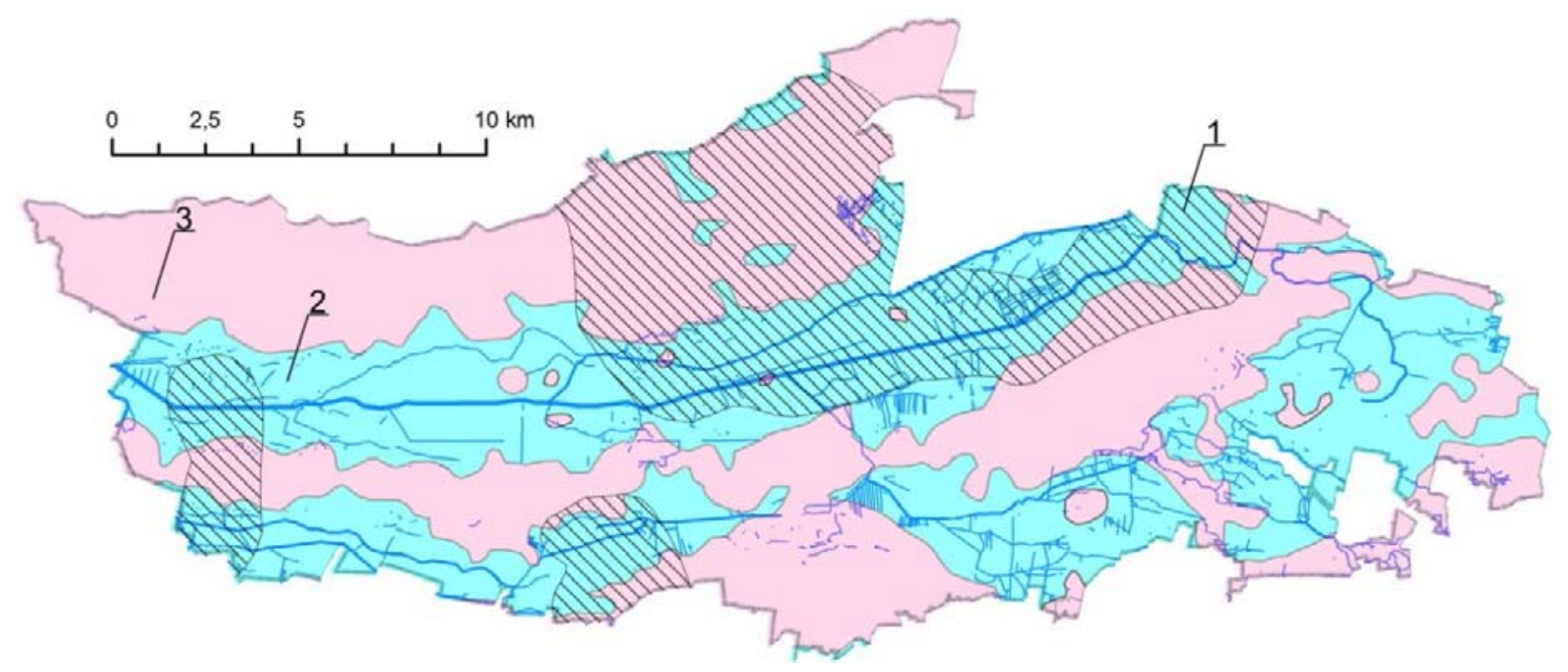

Fig. 4. Groundwater level in the Kampinos National Park: 1 - areas where elevated groundwater levels are being observed, 2 - areas with groundwater table situated above $1.5 \mathrm{~m}$ below ground level, 3 - areas with groundwater table situated below $1.5 \mathrm{~m}$ below ground level

channels and ditches, including the Łasica Channel. In other words, it would be a step towards recreation the natural conditions that existed in this area before construction of the drainage system. But this solution is very difficult to achieve both because of the costs and risk for the environment that arise from the use of technology and machines. Construction of various partitions (thresholds) of the fixed crown or with the valves that allow adjusting water level in streams is more reasonable in terms of economy and technology. This kind of construction limits the outflow from the wetlands by retention of water for use in precipitation less periods. Certain steps in this direction have been taken. Eight weirs with passages for fish have been constructed on the Lasica Channel. These weirs had been constructed to sustain water conditions allowing agricultural use of the terrains adjacent to the Lasica
Channel. The additional function of these weirs was to protect the wetlands but a proper water management of the weirs has never been implemented and some of them have been destroyed. There are no available information if water passages for fish had ever worked.

A significantly greater number of damming devices located on channels and ditches is needed to protect the natural value of wetlands. A schematic proposal of reconstruction of the hydrographic system of the Park to sustain high humidity level of wetlands has been presented on Figure 5. Construction of many small damming devices with the fixed threshold as well as some bigger weirs adjusted to water damming throughout the year is expected. In order to give a more natural character to the watercourses activation the chosen local depressions has been suggested.

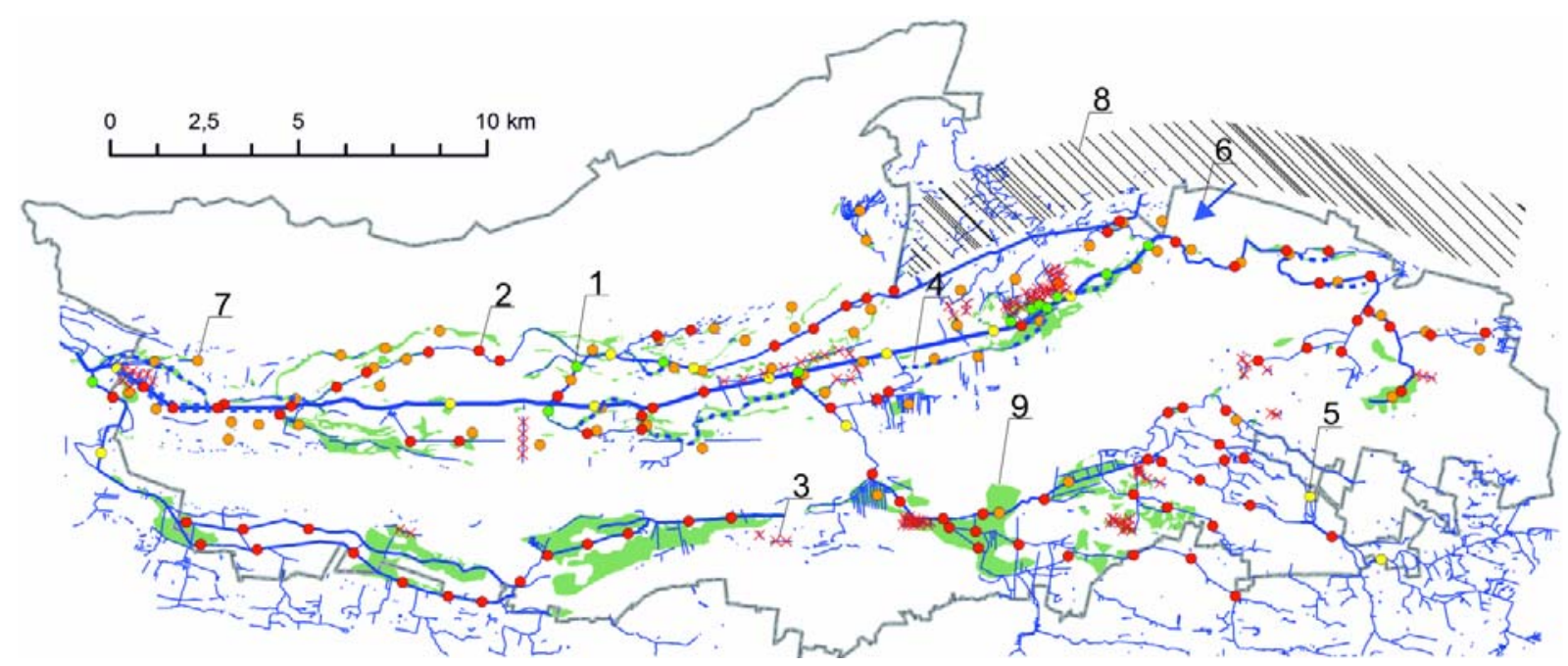

Fig. 5. The simplified map of the technical measures: 1 - planned constructions with possibility of water level regulation, 2 - thresholds with the fixed crown, 3 - ditches for liquidation, 4 - watercourse meandrization, 5 - existing constructions, 6 - possible water recharge from the Vistula River, 7 - dried out sites (degradation), 8 - sites flooded in July 2011, local depressions 
Water supply to these natural depressions will cause that the Łasica Channel will gain a character of a meandering river. The additional element limiting the fast runoff of water can be abandoning of the maintenance of watercourses. Vegetation developing in the riverbed will cause increase the hydraulic resistance and thus elevation of the water level with the same flow rate. All the suggestions given above are only preliminary that do not have any legal status and their implementation requires an agreement of the local population.

In July 2011 high precipitation causing increase of the surface- and groundwater table level occurred in the Park and the adjacent areas. It was a positive phenomenon from the environmental protection point of view. On the other hand, it caused numerous economic damages as a result of buildings flooding, also in the areas adjacent to the borders of the Park. Many properties were flooded and water remained on the yards and roads for a long time. Attempts to drain water by digging small grooves gave no result. In one of the settlements it has been decided to dig up across the asphalt road to allow water drainage. All these measures did not give the expected results as the only direction of water runoff in the Park is towards wetlands and local drainage system. Water level in the wetlands was sometimes higher than in the surrounding mineral soils. It was a result of the low hydraulic conductivity of the Lasica Channel and silted ditches covered by plants.

The simplest solution to prevent flooding of the built-up areas would be to restore water flow in the Lasica Channel and in the most of the smaller ditches and grooves locater in the Park. Restoration of water flow would mean cut off of the vegetation present in the riverbed as well as silt removing that would increase the cross-section. It would be the simplest solution. These measures would cause not only a fast runoff of the precipitation but also further lowering of the of the groundwater level and as a consequence - increase of the organic soil degradation processes and unfavourable changes in fauna and flora. From the technical point of view it would be possible to construct devices allowing regulation of water level in these watercourses but it would be an expensive and highly complex system demanding water recharge from the Vistula River to maintain high water level in the wetlands area.

A situation that occurred in July 2011 was possible to predict. Similar floods happened before but they were not that annoying to the local population as the total number of buildings, number of buildings with basements with floor situated below the ground level, number of septic tanks and small treatment plants localized mostly in the local depressions were lower. Protection of individual or group of buildings against flooding might be effective in this area. It would be a difficult but feasible task due to the lack of a reservoir that might receive and retain water from the drainage system. However, even more important task is to define areas with special requirements with regard to the location of buildings in the local spatial management plan. In the area of the Kampinos National Park at least four zones can be defined: 1) zone where construction of any buildings will be prohibited, 2) zone where buildings might be constructed only on artificial elevations with a mechanical treatment plants located beyond the flooding area, 3) zone where buildings without basements and with a mechanical treatment plants located beyond the flooding area would be allowed, 4) zone without any restrictions.

\section{SUMMARY}

Implementation of the idea of wetlands protection (water related ecosystems) surrounded by the areas used for economical purposes, including farming, is w difficult task. Often, local population is forced to cover costs of the protection but on the other hand, it also happens that people for their own "convenience" expose themselves to the negative impact of water excess due to lack of the basic knowledge. In many cases it is easy to find a compromise but there are also cases when finding a solution satisfactory to all interested parties is difficult. Such examples cases have been described above. A compromise solution is possible to find in the case of flooding of the Brzozówka estuary section. If one decides to remove silt of the river bed will not harm the natural environment of the Biebrza National Park (although it is not a measure that can be named indifferent to the nature) it can be assumed as a compromise solution. It would only demand improvement of the quality of the earth works which is perfectly possible to achieve. If it turned out that cutting off the vegetation and removing silt of the riverbed (with no loss to the natural values of the Park) is not satisfactory to the local farmers compensations (at least partially) for their losses in the yields as a result of excessive humidity of meadows should be considered.

The difficult situation occur in the Narew National Park. In the present situation it is almost impossible to find a solution that would be satisfactory to all parties - the National Park, PTOP as an owner of the buffer zone and farmers from the Rzędziany village. Keeping the low damming level on the weir Rzędziany and liquidation of the damming threshold will destroy wetlands ecosystems at the length of at least several kilometres along the river. On the other hand, experience from the past several years show that operating of the weir in a way that would satisfy all interested parties would be extremely difficult, if not impossible, task. The most reasonable solution would be to purchase the flooded grasslands situated in the limits of the National Park above the dike and 
to take over of the weir in Rzędziny by the Park. Only under these circumstances operation of the weir would be conducted in accordance with the requirements of the protection of the natural values of water dependent ecosystems. Under these conditions it would be also possible to supply water to the restored part of the buffer zone.

A very complex situation occurs in the Kampinos National Park. It is not possible to allow flooding of the inhabitant buildings and septic tanks and mall sewage treatment plants located in the area. But it is also not possible to allow degradation of wetlands located in the Park as a result of drying. It seems that it is the site where finding a compromise is not easy and man give way to the nature or to secure himself from its negative impact.

\section{Acknowledge}
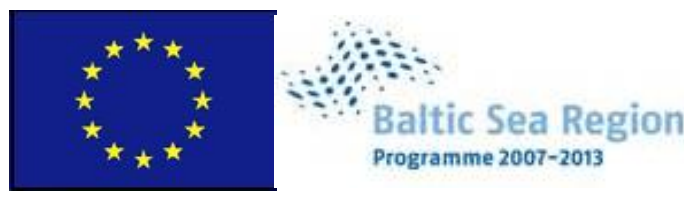

Part-financed by the European Union (European Regional Development Fund and European Neighbourhood and Partnership Instrument)

\section{REFERENCES}

A practical guide to stream and wetlands care. 2000. The stream keepers handbook. Montreal. Province of British Columbia pp. 46

MioduszewsKi W., DemBeK W. (eds.) Woda na obszarach wiejskich. [Water in the rural areas]. 2009. Falenty. MRiRW. IMUZ. ISBN 978-61875-09-3 pp. 448.

OKruszko T., Mioduszewski W., KUCHARSKI L. (eds.) 2011. Ochrona i renaturyzacja mokradeł Kampinoskiego Parku Narodowego. [Protection and restoration of wetlands in the Kampinos National Park]. Warszawa. SGGW. ISBN 978-83-7583-275-4 pp. 238.

Opracowanie ustalające przyczynę podtopienia użytków rolnych wsi Rzędziany i Radule gmina Tykocin. [Study defining the reason of flooding of the agricultural lands in Rzędziny and Radule villages in the community of Tykocin]. 2011. Starostwo Powiatowe w Białymstoku. Białystok (Ed. Z. Lenczewski).

PTOP 2011. Renaturalizacja strefy buforowej Narwiańskiego Parku Narodowego. [Restoration of the buffer zone of the Narew National Park]. Informacja o realizacji projektu. Białystok pp. 13

Zrównoważone korzystanie $\mathrm{z}$ wód rzeki Brzozówka na obszarze Biebrzańskiego Parku Narodowego. [Sustainable use of water from the Brzozówka River within limits of the Biebrza National Park]. 2009. Operat wnioskowy. Koordynacja: T. Okruszko. Maszynopis. Warszawa pp. 78.

ŻBIKOWSKI A., ŻELAZO J. 1993. Ochrona środowiska w budownictwie wodnym. [Environmental protection in water engineering[. Materiały informacyjne. Warszawa. MOŚZNiL.

\section{Waldemar MIODUSZEWSKI, Tomasz OKRUSZKO}

\section{Ochrona naturalnych mokradel - przykłady konfliktów}

\section{STRESZCZENIE}

\section{Słowa kluczowe: gospodarka wodna, mokradła, ochrona środowiska, parki narodowe}

Konieczność ochrony terenów mokradłowych nie budzi wątpliwości. Są to zazwyczaj obszary o dużych walorach przyrodniczych, tworzące siedlisko o dużej różnorodności biologicznej. Zachowanie takich obszarów wynika nie tylko z ich dużych walorów przyrodniczych, ale są one bardzo ważnym czynnikiem, wpływającym na jakość i ilość zasobów wody. Powodując spowolnienie odpływu wody ze zlewni, ograniczają transport związków biogennych, a tym samym przyczyniają się do ochrony jakości wód powierzchniowych i podziemnych na terenach rolniczych. Zachowanie mokradeł, mimo powszechnej akceptacji stwarza wiele sytuacji konfliktowych. Zachowanie cennych walorów przyrodniczych wymaga utrzymania dużego uwilgotnienia gleb i wysokiego poziomu wód podziemnych. W przypadku, gdy chronione tereny lub przyległe do nich są użytkowane przez rolników lub znajdują się tam zabudowania, występuje wyraźny konflikt interesów.

W artykule przedstawiono analizę konfliktów, które wystąpiły za granicą trzech parków narodowych: Kampinoskiego, Narwiańskiego i Biebrzańskiego. Opisano źródło tych konfliktów i ewentualne możliwości pogodzenia interesów przyrody z interesami gospodarczymi (użytkowanie łąk i pastwisk, zabudowa mieszkaniowa). Dotyczyły one głównie potrzeb i ograniczeń utrzymania rzek, poprzez okresowe usuwanie roślinności z koryta rzeki oraz jego odmulania. Zarastające koryta rzeki powodują podwyższenie poziomów wody w ciekach i zwiększenie uwilgotnienia gleby, co skutkuje niekorzystnymi warunkami wodnymi dla roślin uprawnych lub powoduje zalania dróg i terenów zabudowanych. 